IRA-International Journal of Management \& Social Sciences

ISSN 2455-2267; Vol.07, Issue 02 (2017)

Pg. no. 244-249

Institute of Research Advances

http://research-advances.org/index.php/RAJMSS

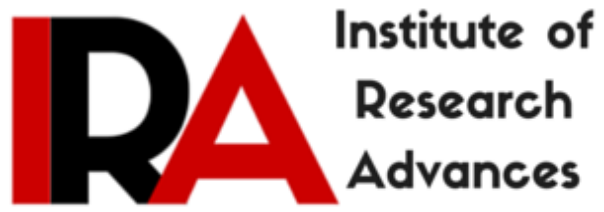

\title{
Major Concerns for Education Loans in Kerala
}

\author{
Minu John \\ Research Scholar \\ School of Management Studies \\ Cochin University of Science \& Technology (CUSAT), India.
}

Type of Review: Peer Reviewed.

DOI: http://dx.doi.org/10.21013/jmss.v7.n2.p14

\section{How to cite this paper:}

John, M. (2017). Major Concerns for Education Loans in Kerala. IRA-International Journal of Management \& Social Sciences (ISSN 2455-2267), 7(2), 244-249.

doi:http://dx.doi.org/10.21013/jmss.v7.n2.p14

(C) Institute of Research Advances

\section{(cc) EY-NC}

This work is licensed under a Creative Commons Attribution-Non Commercial 4.0 International License subject to proper citation to the publication source of the work.

Disclaimer: The scholarly papers as reviewed and published by the Institute of Research Advances (IRA) are the views and opinions of their respective authors and are not the views or opinions of the IRA. The IRA disclaims of any harm or loss caused due to the published content to any party. 


\section{EDUCATION IN KERALA}

The importance of education loan us underscored by the state' ranking as the most literate in the country. The local dynastic precursors of modern day Kerala- primarily the Travancore Royal Family, the Christian Missionaries, the Nair Service Society, Sree Narayana Dharma Paripalana Yogam (SNDP Yogam) and Muslim Educational Society (MES) -made significant contributions to the progress on education in Kerala. There were many sabtha mathams that imparted Vedic knowledge. Apart from kalaris, which taught martial arts, there were village schools run by Ezuthachans or Asans. Christian missionaries brought the modern education system to Kerala.

Education in Kerala had been promoted during British rule in India by Christian missionaries who were keen on providing education to all sections of society and on strengthening of women, without any kind of discrimination. The contributions of catholic priests and nuns have been crucial and have played a major role in the education of women and members of lower strata of society, resulting in the surpassing of many social hurdles. A significant figure in the $19^{\text {th }}$ century was Rev. Fr. Kuriakose Elias Chavara, who started a system called "A school along with every church" to make education to the poor and rich. That system still continues in the present. His work has resulted in the promotion for girls and has become a model for the educational system in Kerala after independence. Kerala's high literacy rate in the promotion of education for girls and has become a model for the educational system in Kerala after independence. Kerala's high literacy rate is attributed to a high literacy rate among girls; since, "When a woman is educated, she will make sure that her children are well educated".

\section{Issues of Concern in Education in Kerala.}

There are indeed a few more important aspects that may be of concern. It is widely held that there has been a drastic decline in the quality of higher education to unacceptable levels, and such a poor quality education will not contribute to development - economic, social and political. Second, higher education is found to be increasingly becoming less and less affordable by a vast majority. The rising household costs of higher education testify this. The high increase in household costs will pose problems in ensuring an inclusive higher education system. The third related problem is the increasing graduate unemployment in the state. According to the Human Development Report 2005 of Kerala (Government of Kerala 2006), Kerala experiences the highest rate of unemployment.

The rapid growth in self-financing private sector, led to diminution of public sector and public sector displacement in a big way. Number of students in government and government-aided colleges is found to be declining, as the students are shifting to self-financing colleges.

In Kerala, we find self financing colleges not only under private sector, but also under government sector. The main agencies in the government's self-financing sector are the Institute of Human Resource Development (IHRD) and LBS Centre for Science and Technology. There are also self financing colleges under the government sector under several bodies such as KSRTC (Kerala State Rod Transport Corporation), CAPE (Co-operative Academy of Professional Education), CCEK (Centre for Continuing Education Kerala), and Academy of Medical Sciences (KNM). The NORKA (Non-resident Keralites Department of the Government of Kerala) also has recently announced their plans to start self-financing professional colleges avowedly for the benefit of non-resident Keralites. Further, there are also self financing colleges under state universities and under private deemed universities. In addition, there are self financing private colleges and also such colleges under private agencies such as Kerala Catholic Engineering College Managements' Association. To check the problem of lack of social control of the government over the private self-financing institutions, the government promoted the formation of student-funded professional colleges in the cooperative sector. The societal control on many of these institutions is debatable (Kumar and George 2009).

As highlighted by Kumar and George (2009), there are also several 'non-formal' higher education institutions which are not affiliated to any university or to the government, but are offering several job-oriented courses purely on commercial basis. Though reliable data are not available on these institutions, it is largely believed that the students numbers enrolled in these institutions are not small. 
At the same time, privatisation of public higher education is also taking place at a rapid rate, through increase in student fee, increase in student loan programmes, and introduction of self financing courses in public universities/colleges on a large scale. As Varghese (2006) described, privatisation of public assets is taking place in higher education in Kerala through the aided colleges, which are also really public wealth, as they are created with the help of public funds. Public assets are created by the government and for some time these functioned within the parameters of social control. These assets are now freely operated by private managements for running courses of their choice and are being gradually transferred to individual or corporate managements in the state.

As a result of all these development, there is a serious decline in 'public'ness in higher education including specifically in public higher education. The high proportion of exclusively-fee-relying financing colleges and other measures of increasing privatisation of public higher education pose serious problems on enhancing equitable access to higher education, besides posing serious problems in terms of producing low quality graduates in large numbers resulting in accentuating the graduate unemployment.

\section{OBJECTIVES OF THE STUDY}

1. To know some basic issues in Higher education sector.

2. To know the current issues in education loans in Kerala.

3. To know the outstanding education loans in Kerala

4. To know the NPA position of education loans in Kerala

\section{SIGNIFICANCE OF THE STUDY}

This study is intended to know the current situation of education loans in Kerala. Each year there are many improvements or revolutions in education loans. Last year Reliance ARC purchased Rs 63 crore Nonperforming Assets of education loans from public bank SBT. They were threatening to repay the loans; otherwise they will be attaching the pledged properties of loan beneficiaries.

Chief Minister Mr. Pinarayi Vijayan announced a plan that will help these people who are on the verge of losing their properties and being pressurized to commit suicide. Thus education loan issues in Kerala are always having some remarkable change year to year. Thus a study is needed to address these issues

\section{Issues in education loans in Kerala}

Issue 1

In Kerala educational loan gained importance, with the suicide of Ms Rajini, a Dalit engineering student in 2004 who was denied education loan. There was a huge uproar across various sections of the State which led to relaxation of norms of the operation of the scheme. The secondary data reveal that in Kerala, student loans sanctioned (by all banks) increased from 33800 (Rs 63811 lakhs) in 2005-06 to 61501 (Rs 162448 lakhs) in 2008-09. In case of public sector banks loans sanctioned increased from 28116 to 52874 during the same period. The number of loans outstanding has more than doubled (from 111572 to 229963 ) while the amount of outstanding also increased by $178 \%$. The number of NPA loans increased from 2016 in 2005 to 8926 in 2008-09, an increase of approximately 500\% (from 1939 lakhs to Rs 11385 lakhs) in the last four years. (Soumya Vinayan 2012) 


\begin{tabular}{|l|c|c|c|c|c|c|c|}
\hline \multicolumn{7}{|c|}{ TABLE 1: Growth in Student Loans in Kerala (All Banks) (Amount in Lakhs) } \\
\hline Year & \multicolumn{7}{|c|}{ Number of Loan } \\
\cline { 2 - 8 } & Applications & \multicolumn{2}{|c|}{ Sanctioned } & \multicolumn{2}{c|}{ Outstanding } & \multicolumn{2}{c|}{ NPA } \\
\hline & No & No & Amt & No & Amt & No & Amt \\
\hline $2005-06$ & 34855 & 33800 & 63811 & 111572 & 134120 & 2016 & 1939 \\
\hline $2006-0$ & 46949 & 45224 & 584376 & 147633 & 187112 & 1887 & 1697 \\
\hline $2007-08$ & 45276 & 43078 & 106612 & 180487 & 268234 & 5720 & 8386 \\
\hline $2008-09$ & 69300 & 61501 & 162448 & 229963 & 372519 & 8926 & 11385 \\
\hline \multicolumn{7}{|c|}{ Source: SLBC, Canara Bank Circle Office, Trivandrum } \\
\hline
\end{tabular}

In order to understand more about the significance of education loans in Kerala, one should analyse the quantity of loans sanctioned, disbursed, outstanding and classified as NPA vis-à-vis state budget allocations for General and Technical education Under General, for the purpose of analysis, only allocation for University and Higher Education is considered. It is evident from Table 2 that in the year 2005-06, the sanctioned loan amount disbursed in 2005-06 was worth 55\% of budget allocation and this figure stood at $148 \%$ in 2008-09. Likewise, an outstanding equivalent to $204 \%$ of budget allocation in 2005-06 while this had steadily increased to $377 \%$ in 2008-09. In terms of NPA, the NPA accounted for 3\% of budget allocation in 2005-06 while it increased to $12 \%$ in 2008-09. These figures raise serious concern and draws attention to the need to understand the implementation of education loans in the state.

Table 2: Budget Allocation for Higher \& Technical education by Government of Kerala vis.a vis Student loans (Amt in Lakhs)

\begin{tabular}{|c|c|c|c|c|c|c|c|c|c|c|c|}
\hline \multicolumn{9}{|c|}{ Budget Allocation } & \multicolumn{4}{c|}{ Amount of loan sanctioned } & \multicolumn{3}{c|}{$\begin{array}{c}\text { Student loan as a percentage of } \\
\text { Allocation }\end{array}$} \\
\hline Year & GE & TE & Total & $\begin{array}{c}\text { sanction } \\
\text { ed }\end{array}$ & $\begin{array}{c}\text { disburse } \\
\text { d }\end{array}$ & $\begin{array}{c}\text { Outstandi } \\
\text { ng }\end{array}$ & NPA & $\begin{array}{c}\text { sanct } \\
\text { ioned }\end{array}$ & $\begin{array}{c}\text { disbur } \\
\text { sed }\end{array}$ & $\begin{array}{c}\text { Outsta } \\
\text { nding }\end{array}$ & NPA \\
\hline Mar-06 & $\begin{array}{c}5016 \\
8\end{array}$ & 165664 & 65832 & 63811 & 36250 & 134120 & 1939 & 97 & 55 & 204 & 3 \\
\hline Mar-07 & $\begin{array}{c}5381 \\
5\end{array}$ & 17351 & 71166 & 58436 & 41987 & 187112 & 1697 & 82 & 59 & 263 & 2 \\
\hline Mar-08 & $\begin{array}{c}6036 \\
5\end{array}$ & 17152 & 77517 & 1 E+05 & 61514 & 268234 & 8386 & 138 & 79 & 346 & 11 \\
\hline \multicolumn{10}{|c|}{ Source: (Soumya Vinayan 2012) } \\
\hline
\end{tabular}




\section{Default situation in Kerala.}

\begin{tabular}{|c|c|c|c|c|c|c|c|}
\hline \multicolumn{7}{|c|}{ Number of Loans } \\
\hline & & \multicolumn{2}{c|}{ Sanctioned } & Outstanding & \multicolumn{2}{c|}{ NPA } \\
\hline & & & & & & & \\
Year & Applications No & No & Amt & No & Amt & No & Amt \\
\hline Mar-12 & 63667 & 62690 & 138062 & 353795 & 705788 & 28367 & 49045 \\
\hline Mar-13 & 51277 & 50277 & 140560 & 380295 & 829454 & 47661 & 76255 \\
\hline Mar-14 & 56102 & 57314 & 126069 & 390237 & 919917 & 48098 & 95842 \\
\hline Mar-15 & 50111 & 47305 & 115774 & 393849 & 956843 & 34398 & 74647 \\
\hline Mar-16 & 43662 & 47042 & 153199 & 369829 & 969182 & 43644 & 109389 \\
\hline \multicolumn{7}{|c|}{ Performance report of various years by SLBC Kerala } \\
\hline
\end{tabular}

From the table we can see that total outstanding loans in Kerala in have been increasing on a continuous rate from Rs 705788 . The Non performing assets (in Amt) increased on a continuous rate till March 2014; (Rs. 95842) it declined in March to (Rs.74647) in 2015 and then increased in March 2016 to Rs 109389 lakhs.

\section{Issue 2 - Purchase of NPAs by Reliance ARCs from SBT}

Student loans are becoming a crisis in Kerala where parents are under tremendous pressure to avail higher education after borrowing money from banks and private money lenders and pledging jewellery. Statistics show that banks have sanctioned a total of Rs77, 885 crore to 331663 student borrowers in Kerala until March 2015, which is second only to Tamilnadu where Rs1, 63130 crore was given to 960202 .

The economic slowdown triggered by the global financial crisis of 2008 has meant there are fewer jobs in many sectors, including software services. There have been drastic job-cuts across the industrial sector, and the once-flourishing nursing sector, to which Kerala was a major supplier of human resource until recently, still now it has not been able to recoup back.

In July last year, public sector bank State bank of Travancore has sold its education NPAs of Rs 130 crore, to be recovered from 8568 defaulters, to R-ARC for Rs 63 crore. Reliance paid Rs 9 crore to the bank immediately and gave security receipt for Rs 54 crore. It could pay the money to the bank within a time frame of 15 years. R-ARC was sending notices and threatening that the property of borrower's families will be pledged.

\begin{tabular}{|c|c|c|c|c|c|c|c|c|}
\hline \multicolumn{8}{|c|}{ Table 4 : Outstanding Education loans (Amt in Lakhs) } \\
\hline \multirow{2}{*}{ Year } & \multicolumn{2}{|c|}{$<$ Lakhs } & 4lakhs -7.5 lakhs & Above 7.5lakhs & \multicolumn{2}{c|}{ Total o/s } \\
\cline { 2 - 10 } & No & Amt & No & Amt & No & Amt & No & Amt \\
\hline Mar-12 & 312664 & 524485 & 27201 & 88111 & 19168 & 103163 & 359013 & 721603 \\
\hline Mar-13 & 348149 & 662045 & 21124 & 85698 & 10003 & 76647 & 380295 & 829454 \\
\hline Mar-14 & 291937 & 593075 & 36127 & 148012 & 10409 & 77407 & 334873 & 818494 \\
\hline Mar-15 & 327007 & 681374 & 48767 & 169663 & 18076 & 105806 & 393849 & 956843 \\
\hline Mar-16 & 304415 & 650261 & 43943 & 185075 & 21471 & 133845 & 43644 & 109389 \\
\hline
\end{tabular}


From the table we can analyse each category of loan payers according to the amount of loan taken by the benefiaries. From the table it is evident that the outstanding position of education loans is high, where the amount is less than Rs. 4 lakhs. It is because for loans below Rs 4 lakhs there is no collateral security or personal guarantee to be provided to the banks.

\section{Issue 3 - Relief to the Beneficiaries.}

Recently in 2017 Chief Minister Pinarayi Vijayan has announced a support scheme to help students from financially backward families repay education loans. This scheme was designed to help families facing revenue recovery (especially those who are facing threats from the ARC's) after finding themselves unable to repay the loan. The scheme would be effective from April 2016 and would be applicable to loans up to Rs 9, 00,000. The government would share $90 \%$ of the repayment liability in the first year, $75 \%$ in the second year, $50 \%$ in the third year and $25 \%$ in the fourth year.

For bad loans up to Rs 4, 00,000 availed before April1, 2016 the government would bear 60\% of the repayment liability if the bank waived the interest. For loans between Rs4, 00,000 and Rs 9, 00,000 the government would $50 \%$ of the principal amount up to a maximum of Rs 24000 on a special package for closure of the loan. Mr. Pinarayi Vijayan said that the government would bear the repayment liability in the case of student's demise or handicap due to an accident, provided the bank was ready to waive the interest. According to an estimate prepared by the State Level Bankers Committee, Kerala, this scheme would cost the government Rs 900 crore.

\section{Conclusion}

Increasing fees rate of self-financing colleges is one of the major reasons that most of the students take education loans. The skyrocketing fees of self financing colleges motivate them to take education loans. Most of the beneficiaries take loan with the hope of repaying it after their graduation. But in reality they end in unemployment or underemployment. The study of Soumya Vinayan (2012) found that majority of the students borrow to pursue career in the field of Nursing especially in private institutions situated outside the state. Data also reveals that majority of them were not selected to these institutions through entrance exams nor did they perform well in their qualifying exams. Moreover, the levels of repayment were very low given the limited job opportunities and low levels of income leading to high levels of indebtedness among the student borrowers. Thus education loan becomes a debt trap for those people. Government should take measures the control the fees of selffinancing colleges. But every year the fees of self-financing colleges are being increased at an increased rate and the number of government aided colleges are being inappropriate to handle all the students. Government should seek measures to bring more aided colleges so that loan burden of students can be reduced.

\section{References}

1. www.wikipedia.com

2. www.indianexpress.com

3. www.decanherald.com

4. Tilak, J. B. (2001). Jandhyala B G Tilak. Kochi: Centre for Socio-economic \& Environmental Studies .

5. Vinayan (2012). Student's loans in financing higher education: levels of Indebtedness among students borrowers in kerala. Hyderabad Social development Papers, 1, (4) 31-37.

6. Varghese K.X \& Manoj P.K, Efficacy of Educational Loans: Employability of the Borrowers is the most important Predictor. Volume: 2 Issue: 1 ISSN No 2277-8160 